\title{
Apple Cider Vinegar (ACV) and their Pharmacological Approach towards Alzheimer's Disease (AD): A Review
}

\author{
Smriti Tripathi, Papiya Mitra Mazumder* \\ Department of Pharmaceutical Sciences and Technology, Birla Institute of Technology-Mesra, Ranchi, Jharkhand, INDIA.
}

\begin{abstract}
Alzheimer's disease (AD) is a neurological degenerative condition described by a progressive decline in memory and associated with dementia. This disease arises usually after 65 years in individuals. Oxidative stress is the major cause of dementia connected with Alzheimer's disease. Here there is an imbalance between the creation and clearance of amyloid $\beta$ protein, which leads to accumulation of amyloid $\beta$ plaque in the brain and produces neuronal cell death. Anti-Alzheimer's medications help to cover the symptoms of disease but do not cure the cause of disease. Confirmatory studies suggest that a healthy diet of fruits and green vegetables containing phenolic combinations may reduce the risk of Alzheimer's disease (AD). Apple cider vinegar (ACV) contains phenolic compounds like catechin, caffeic acid, gallic acid, chlorogenic acids and p-coumaric acid having high antioxidant potential. Phenolic compounds are not essential for survival but it can protect against various chronic diseases. Various researches showed that phenolic compounds cure $\beta$ amyloid and tau protein correlated problems associated with AD. Regular consumption of these healthy substances in the diet may prevent the neuronal cells from oxidative stress which leads to AD. The purpose of this review is to highlight the health benefit role, functional property and therapeutic uses of Apple Cider Vinegar.
\end{abstract}

Key words: Apple Cider Vinegar, Alzheimer's disease, Oxidative stress, Phenolic compounds, $A \beta$ aggregation, Pharmacological activities.

\section{INTRODUCTION}

The lifestyle of humans is mostly connected with the developing of numerous complicated neurological conditions associated with aging. These conditions include intellectual abilities, language problems and memory loss. The prolonged state of these symptoms together develops intellectual deficits in the elderly and is commonly mentioned as dementia. It is predicted that 46.8 million people in this world have dementia and incidences are expected to grow every year and it would be 131.5 million in $2050 .^{1,2}$

Alzheimer's disease (AD) is the most predominant neural condition associated with dementia. The most troubling complicationassociated with AD is forgetting daily routine functions. Although the mechanism behind this neurodegeneration is completely unknown but several genetic and environmental factors, together with vascular pathology have recently shown the growth and progression of Alzheimer's disease. $^{3}$

In Alzheimer's disease (AD), an individual may seem to be fit but has more and more distress making sense. The problem associated with AD includes memory loss, poor judgment for making decisions, loss of spontaneity, time taking normal daily activity, repeating questions, mood and personality changes and anxiety and aggression. The major cause of $\mathrm{AD}$ is due to amyloid $\beta$ protein (amyloid plaque) aggregation outside the neuronal cells and intracellular Tau protein hyper-phosphorylation
Submission Date: 01-11-2019; Revision Date: 06-02-2020; Accepted Date: 12-03-2020

DOI: 10.5530/ijper.54.2s.62 Correspondence: Dr. Papiya Mitra Mazumder Professor, Department of Pharmaceutical Sciences and Technology, Birla Institute of Technology, Mesra Ranchi-835215, Jharkhand, INDIA.

Phone: +919431327044

E-mail: pmitramazumder@ bitmesra.ac.in

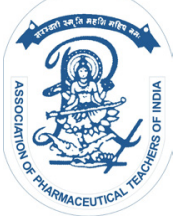

www.ijper.org 
composed of neurofibrillary tangles (NFTs) and loss of cholinergic system functions ${ }^{4}$ shown in Figure 1.

\section{Occurrence of Alzheimer's disease}

In 2005, Alzheimer's disease InternationalCommissioned group spread consensus on dementia and created an epidemiological document acquired over recent years. The outcomes showed that 24.2 million people suffered with dementia and 4.6 million new patients arising every year. ${ }^{5}$

Expected growth rate of dementia incidence from 2001 to 2040 is $172 \%$ and $102 \%$ in Western Europe and North America higher prevalence of dementia $(172 \%$ and $102 \%)$, China more than $300 \%$, Latin America 400\%, North Africa and Middle Eastern Crescent 385\%. The annual incidence rates increased exponentially with age after 65 years. ${ }^{6}$ There is nearly a 15-fold increase in the frequency of dementia, predominately Alzheimer's disease between the ages of 65 to 85 years $^{5,6}$ (Figure 2).

\section{Mechanism of Alzheimer's disease}

Alzheimer's disease (AD) persuaded dementia is typically represented with synaptic injuries and loss of neurons through propagation of microglial cells. ${ }^{7-9}$ Based on new studies, neurodegeneration of the hippocampal neurons, cortex and limbic region of brain is a probable mechanism involved in AD. ${ }^{9}$ Alzheimer's disease is characterized by the two major hallmarks: extracellular aggregation of $\beta$-amyloid $(A \beta)$ and intracellular accumulation of tau protein. Both of these complexes are insoluble in nature. $A \beta$ is the main factor of senile plaques and tau phosphorylation forms neurofibrillary tangles.

Amyloid $\beta$ protein is composed of 36 to 43 amino acids which are a part of APP (amyloid precursor protein). APP is a trans membrane protein, produced by neurons and other brain cells. This protein is present in extraneuronal tissues. The $A \beta$ is the part of the trans membrane domain of APP and is derived by the cleavage of APP with $\beta$ and $\gamma$-secretase enzymes. An imbalance between the production and metabolism of amyloid $\beta$ protein produces toxicity in neurons synapses. Formation of $A \beta$ protein is typically mediated by the activity of enzyme including $\gamma$-secretase and BACE- 1 metabolism of $A \beta$ protein is produced by an active proteolytic enzyme ApoE (chaperone) besides lysosomal and non-lysosomal pathways. ${ }^{10-12}$ These $A \beta$ monomers are polymerized into insoluble $A \beta 42$ oligomers, which participate in amyloid accumulation.

These A $\beta$ residues produced microglial infiltration, formation of ROS (reactive oxygen species), synaptic damage, neurotoxicity and neurodegeneration. Additionally $A \beta$ aggregations also initiate hyperphosphorylation of tau protein and their cleavage (Figure 3). This phosphorylation and cleavage is induced by $A \beta$ activated enzyme such as CDK5, GSK-3 $\beta$ and caspases. These enzymes induce tau phosphorylation and formation of intracellular neurofibrillary tangles which are insoluble inclusions. ${ }^{13-15}$ Tau accumulates as a pair of fibers which are twisted around one another and formed paired helical filaments structure (PHFs) (Figure 3).

\section{Risk Factors Associated With Alzheimer's}

Numerous features have been associated with AD. Diabetes, cardiovascular complications, obesity, dyslipidemia and smoking has found to increase the risk of Alzheimer's disease in old age ${ }^{16}$ (Table 1, Figure 4). Remarkably cerebrovascular disease including large cortical infarcts, cerebral hemorrhage, hypoperfusion and other effects produces dementia which is associated with Alzheimer's disease. ${ }^{17-23}$

\section{Existing Anti-Alzheimer's Medication}

Prescriptions which prescribe to control the improvement of AD indications become comparatively less effective after some time as Alzheimer's turns out to be worse. Specialists are searching for new strategies to treat Alzheimer's disease (AD). There are various clinical medications produced by pharmaceutical companies for the treatment of Alzheimer's disease. ${ }^{24}$ Rivastigmine, Galantamine and Donepezil mostly act on acetyl cholinesterase and prevent the hydrolysis of acetylcholine, resulting higher concentration of acetylcholine in cerebrum which produces better communication between the neurons. Anti-Alzheimer's medication found in market shown in Table $2{ }^{25}$

\section{Efficacy of Dietary Nutrients in Preventing Alzheimer's disease}

\section{Fatty acids}

Several examinations have explored the properties of polyunsaturated fatty acids (PUFAs) in avoiding or preventing $\mathrm{AD}$. The PUFAs are the important component of cell membrane and maintain the fluidity of membrane which is significant for synaptic vesicle fusion followed by neurotransmitter communication. The PUFAs contain eicosapentaenoic acid (EPA), omega-3 fatty acids and decosahexaenoic acid (DHA). So PUFAs show a significant dietary involvement in preventing the neuronal loss and improving learning and memory. ${ }^{26}$ 


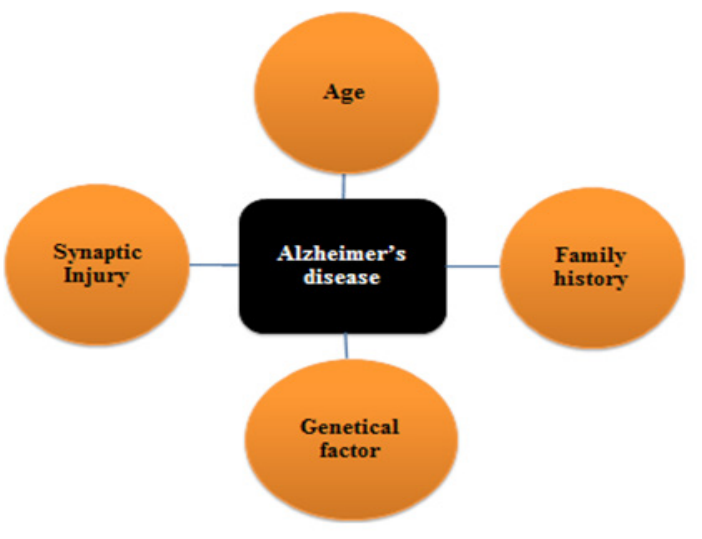

Figure 1: Causes of Alzheimer's disease (AD).

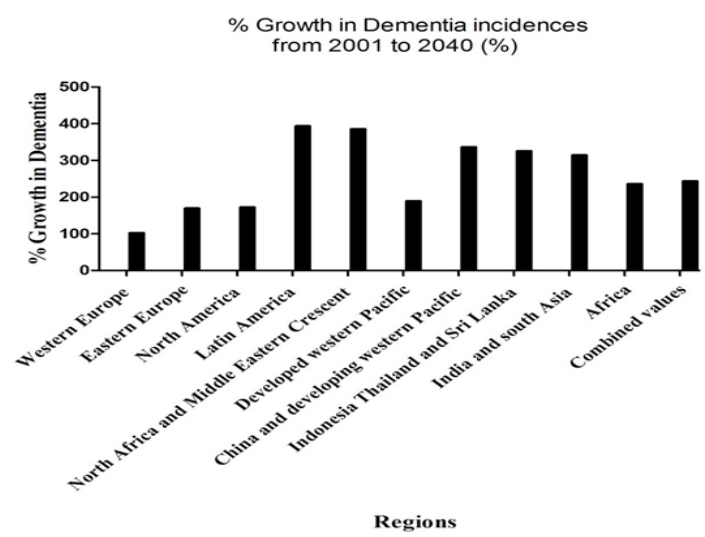

Figure 2: Predictive percentage increase of dementia in developed and developing regions.

\section{Vitamins}

Vitamins have high antioxidants potential and scavenge free radicals effectively. Free radical generation in the brain contributes to progressive failure of cognitive abilities and induces dementia. Clinical trials on vitamin $\mathrm{E}$ supplementation carried out for patients with moderate $\mathrm{AD}$ confirmed that vitamin $\mathrm{E}$ reduces the progression of infection. ${ }^{27,28}$ Other vitamins like Vitamin A and B were found to be lower in the plasma and serum of the geriatric patients with psychological defects. ${ }^{29,30}$ In vitro studies have shown a direct correlation of the presence of Vitamin $A$ and $\beta$-carotene in case of $\mathrm{AD}$ concerning improvement in brain health. ${ }^{31}$

\section{Phenolic compounds}

Dietary phenolic compounds have been prescribed as a potential functional food to prevent memory decline. ${ }^{32}$ Phenolic compounds are regular substances present in plants, natural products, vegetables and fruits. Some polyphenols like 4-O-methyl honokiol, resveratrol, epigallocatechin-3-gallate (EGCG) have been potential

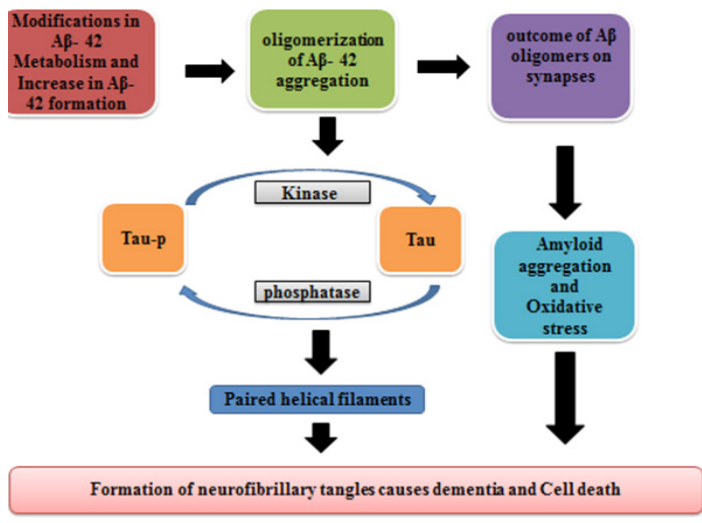

Figure 3: Steps involved in the generation of Alzheimer's disease (AD).

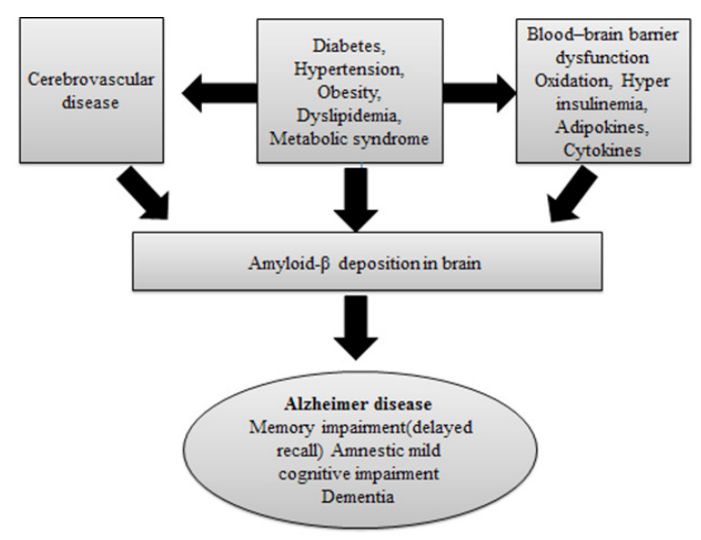

Figure 4: Mechanisms linking vascular risk factors and Alzheimer's disease (AD).

to provide protection against Alzheimer's disease. ${ }^{33}$ Their property might be because of antioxidant and anti-inflammatory properties as well as a variety of chemical enzymatic reactions and intracellular signaling pathways. The neuronal signaling changes with aging by acting on CREB/ERK pathway explain synaptic plasticity and long-term potential effects, refining memory in humans. ${ }^{34-37}$

\section{Phenolic Compounds Found in Different Type of Vinegar}

Polyphenolic compounds of different groups are found in vegetables and fruits. Their biochemical deviations include thousands of combinations from phenolic acids to flavonoids compound. Phenolic compounds have different health beneficial effects, like strong antimicrobial, anticarcinogenic and antioxidant properties which are already reported. ${ }^{38}$ The interest is focused on these compounds due to uniformly higher beneficial fitness properties. Fruits and vegetables also possess health-promoting fibers, phenolic acids, 
Table 1: Factors linked with Alzheimer's disease (AD). ${ }^{16}$

\begin{tabular}{|c|c|c|}
\hline Features & Direction & Mechanisms \\
\hline Obesity & Increased & Diabetes inflammation \\
\hline Smoking & Increased & $\begin{array}{c}\text { Cardiovascular defects, } \\
\text { Oxidative stress }\end{array}$ \\
\hline $\begin{array}{c}\text { Type II Diabetes } \\
\text { Increased } \\
\text { Decreased }\end{array}$ & $\begin{array}{c}\text { Microvascular disease } \\
\text { Insulin and A } \beta \text { compete for } \\
\text { clearance }\end{array}$ \\
\hline $\begin{array}{c}\text { Cardiovascular } \\
\text { Complications }\end{array}$ & Increased & $\begin{array}{c}\text { Parenchymal destruction } \\
\text { In brain, leads to increases } \\
\text { A } \beta \text { deposition }\end{array}$ \\
\hline $\begin{array}{c}\text { Traumatic Head } \\
\text { injury }\end{array}$ & Increased & $\begin{array}{c}\text { Neuronal Cell death } \\
\text { associated with A } \beta \\
\text { Deposition }\end{array}$ \\
\hline $\begin{array}{c}\text { Leisure activity } \\
\text { diet }\end{array}$ & Decreased & $\begin{array}{r}\text { Improves lipid metabolism, } \\
\text { mental stimulation }\end{array}$ \\
\hline Dediteranean & Decreased & $\begin{array}{c}\text { Anti-inflammatory and } \\
\text { Antioxidant }\end{array}$ \\
\hline
\end{tabular}

\section{Table 2: Popular Medications for the treatment of AD.}

\begin{tabular}{|c|c|c|c|}
\hline $\begin{array}{c}\text { Popular } \\
\text { Medications }\end{array}$ & $\begin{array}{l}\text { Phase of } \\
\text { treatment }\end{array}$ & $\begin{array}{l}\text { Targeted } \\
\text { Pathway }\end{array}$ & References \\
\hline Donepezil & $\begin{array}{l}\text { Effective in all } \\
\text { phases }\end{array}$ & AChE Inhibitor & 25 \\
\hline Galantamine & $\begin{array}{l}\text { Mild to } \\
\text { moderate }\end{array}$ & AChE Inhibitor & 25 \\
\hline Memantine & $\begin{array}{l}\text { Moderate to } \\
\text { severe }\end{array}$ & $\begin{array}{l}\text { N-Methyl-D } \\
\text { aspartate } \\
\text { Receptor }\end{array}$ & 25 \\
\hline Rivastigmine & $\begin{array}{l}\text { Mild to } \\
\text { moderate }\end{array}$ & AChE Inhibitor & 25 \\
\hline Tacrine & $\begin{array}{l}\text { Mild to } \\
\text { moderate }\end{array}$ & AChE Inhibitor & 25 \\
\hline
\end{tabular}

vitamins, minerals and flavonoids. Phenolic compounds are not a fundamental element for survival but can provide long term protection against a number of chronic diseases. ${ }^{39}$ there are various phenolic compounds present in different vinegar shown in Table $3 .^{40-43}$

\section{Apple Cider Vinegar}

Apples are essential resources of antioxidants that prevent free radical generation. The apples have high nutritive value and their products are a good source of phenolic compounds, vitamins, minerals, calcium, potassium, phosphorus which are useful in various chronic diseases. Apple cider vinegar is made up from renewed pressed apples, similar to apple juice, treated
Table 3: Vinegars containing phenolic compounds.

\begin{tabular}{|c|c|c|}
\hline $\begin{array}{c}\text { Types of different } \\
\text { Vinegar }\end{array}$ & Phenolic compounds & References \\
\hline $\begin{array}{l}\text { Apple Cider } \\
\text { Vinegar }\end{array}$ & $\begin{array}{l}\text { Gallic acid, catechin, } \\
\text { caffeic acid, epicatechin, } \\
\text { chlorogenic acid and } \\
\text { p-coumaric acid }\end{array}$ & 40 \\
\hline Grape Vinegar & $\begin{array}{l}\text { Catechin, Gallic acid, } \\
\text { chlorogenic acid, syringic } \\
\text { acid and ferulic acid }\end{array}$ & 41 \\
\hline Sherry Vinegar & $\begin{array}{c}\text { Protocatechuic } \\
\text { and Gallic acid, } \\
\text { protocatechualdehyde, } \\
\text { tyrosol, } \mathrm{p}-\mathrm{OH} \text { - benzoic } \\
\text { acid, catechin, p-OH- } \\
\text { benzaldehyde, siringic } \\
\text { acid, vanillin, caftaric } \\
\text { acid, cis-p-coutaric } \\
\text { acid, trans-p-coutaric } \\
\text { acid, fertaric acid, cis- } \\
\text { p-coumaric acid, trans- } \\
\text { p-coumaric acid, ferulic } \\
\text { acid. }\end{array}$ & 42 \\
\hline $\begin{array}{c}\text { Traditional } \\
\text { Balsamic Vinegar }\end{array}$ & $\begin{array}{l}\text { Gallic acid, Furan- } \\
\text { 2-carboxylic acid, } \\
\text { 5- hydroxyfuran- } \\
\text { 2-carboxylic acid, } \\
\text { 4-hydroxybenzoic } \\
\text { acid, vanillic acid, } \\
\text { protocatechuic acid, } \\
\text { syringic acid, isoferulic } \\
\text { acid, p-coumaric acid, } \\
\text { ferulic acid and caffeic } \\
\text { acid }\end{array}$ & 43 \\
\hline
\end{tabular}

in the same way but it is not filtered. ACV is formed from Cider that has undergone acetous bioconversion and contains low acetic acid (less than 5\%), flavonoids, phenolic compounds, organic acids, minerals and vitamins. $^{44}$

\section{Pharmacological Activities of Apple Cider Vinegar}

\section{ACV act as anticancer}

In 2001 Abe $e t$ al..$^{45}$ assessed the antitumor substance of apple cider vinegar against Meth-A fibrosarcoma using female Balb/c mice. In 2005 Barth et al. ${ }^{46}$ used a wellestablished rodent model for persuading colon damage associated with colon cancer by 1,2-dimethylhydrazine and found that cloudy apple juice reduced the DNA damage, hyperproliferation and act as cancer-preventing agent. Pelingo apple juice suppressed the proliferation of breast cancer cells and made cell accumulation in the cell cycle G2/M phase. In addition the apple juice also inhibited 12-o-tetra-decanoylphorbol-13-acetate (TPA) induced tumor genesis of different cell lines. ${ }^{47}$

Apple polyphenols contain procyanidins, flavonoids, epicatechin, catechin which significantly suppressed 
colon cancer cells. ${ }^{48}$ Polyphenols present in apple cider vinegar has cytotoxicity effects in human urinary bladder cancer cells (TSGH-8301) associated with apoptosis and oxidative stress. ${ }^{49}$ In 2008 Clarissa Gerhauser ${ }^{50}$ has written a review article on Cancer chemoprotective potential of apple components and apple juice. This review enclosed in vivo animal data, as well as clinical data, showed a targeted mechanism of apple products towards cancer.

\section{ACV act as Anti diabetic}

Apple cider vinegar (ACV) that is made from fermentation of Apple juice has been used as a folk medicine for diabetes. Diabetes is the metabolic disorder characterized by the hyperglycemic effect. In 2008, studies of shishehbor et al. ${ }^{51}$ showed the protective effect of ACV on lipid profile in normal and diabetic rats model. Apple derived products modulate the gut microbiota and improved high fat diet-induced body weight gain, hyperglycemia, hyperinsulinemia and other metabolic disorders in rodent models. ${ }^{52}$

The metabolic disorders caused by high fat diet were improved by ACV, which proved antihyperlipidemic effect and prevented the atherogenic effects. ${ }^{53}$ Apple cider vinegar (ACV) produced antihyperglycemic effect by the reduction of inflammatory response, reduced the oxidative stress-related markers and normalized the lipid profiles in the complication of Diabetes. ${ }^{54}$ In 2016, studies of Morgan et al. ${ }^{55}$ observed the protective effect of ACV on type II diabetes management.

Based on the Meta analysis, it has been reported that apple products consumption (apple juice, sauce) was connected with a lower prevalence of obesity. ${ }^{56}$ In 2016 Fathy and Drees ${ }^{57}$ performed a study of cloudy apple juice and apple peel extract on rat pancreas. The apple juice induced antihyperglycemic effects by the reduction of inflammation, modification of the oxidative stress and reduced the lipid profile, proposing a useful target for diabetes mellitus.

\section{ACV act as Anti-inflammatory}

In 2014 Naziroglu et al. ${ }^{58}$ showed that ACV modified serum lipid profile, erythrocyte and liver membrane oxidative stress in mice. Dietary flavonoids isolated from apples reduced the inflammation related markers like interleukin-11, interleukin-2 in intestinal tissue of mice. ${ }^{59}$ Apple polyphenolic compounds reduced the inflammatory response of kidney via decrease the expression and activity of COX-2 in rodent model. ${ }^{60}$

Apple cider vinegar has a number of flavonoids and highly effective polyphenolic compounds (Yang et al. 2010; Budak et al. 2011; Denis et al. 2013), ${ }^{61-63}$ which elucidate the antioxidant potential against oxidative stress, free radical generation in tissues and erythrocytes. In 2011 Budak et al. ${ }^{62}$ determined the cholesterol lowering effect of apple vinegar in rats fed on high fat diets and estimated the serum triglyceride levels, total cholesterol, lipoproteins (HDL, LDL, VLDL) of different groups.

\section{ACV act as Hepatoprotective}

Extract of apple polyphenolic compounds reduced the noxious effect of Aluminum in the liver of rodent species. ${ }^{64}$ Polyphenolic compounds improved the SOD (Superoxide dismutase) and catalase activity associated with ATP synthesis. In 2015 Kuzniak et al. ${ }^{65}$ observed the effect of apple juice on hepatocarcinogenic activity induced in rats. These results indicated that apple juice protects liver damage. In 2015 Moura et al..$^{66}$ conducted a study on rats that exhibited that apple juice was able to prevent genotoxicity and oxidative stress persuaded by Cadmium.

\section{ACV act as the reduction in cardiotoxicity}

Atherosclerosis is a chronic disease connected with inflammatory stimulation and oxidative stress which generates the cardio vascular diseases. In $2018 \mathrm{Wu}^{67}$ proposed a study and results showed that cardiovascular health products produced potential effects with apple cider vinegar to improve atherogenesis, ameliorate inflammation and reduced triacylglycerol in mice serum. Polyphenolic compounds in apple peel extract reduced arsenic trioxide induced cardiotoxicity in $\mathrm{H} 9 \mathrm{c} 2 \mathrm{cells}$. The extract altered the activity of SOD, catalase, glutathione, GSH (Glutathione reductase) and caspase 3. ${ }^{68}$

Apple intake was associated with lower risk of all chronic diseases. ${ }^{69}$ In 1994 Laranjinha et al. ${ }^{70}$ observed that Polyphenolic compounds like chlorogenic acid found in apple cider vinegar which reduced the oxidation of lipoproteins (especially LDLs) and prevented cardiovascular complications.

\section{ACV act as Antioxidants, Antimicrobial and Antifungal}

It was found that ACV consumption increased antioxidants enzymes including SOD and glutathione peroxidase. In $2000 \mathrm{Lu}$ and $\mathrm{Foo}^{71}$ carried out a study that showed the antioxidant and free radical scavenging activity of apple cider vinegar containing polyphenolic compounds. In 2016 Seydim et $_{\text {al. }}{ }^{72}$ made an experimental model on rats for evaluation of the antioxidant potential of apple cider vinegar and grape vinegar. In 2018 Yagnik et al..$^{73}$ observed the antimicrobial activity of ACV against various bacteria like E. coli, Staphylococcus aureus and Candida albicans and also checked microbial protein expression. 
Apple cider vinegar (ACV) also has antifungal activity against candida species involved in denture stomatitis. ${ }^{74}$ In 2011 Hyson wrote a comprehensive review on apples and apples constituents followed by a connective link between the apple products with different chronic diseases and their relationship with human health. ${ }^{75}$ This review contained various in vitro studies and clinical data analysis supported to apple products.

\section{ACV act as the reduction in Cognitive impairments, Immunomodulator}

A number of studies from the Shea et al. ${ }^{76-82}$ produced valuable results of apple juice focused on Alzheimer's disease linked with ageing. In this study aging showed impaired memory functions and oxidative markers in the mice brain. When aged mice received the dilute form of apple cider vinegar in drinking water, there was a significant improvement in cognitive functions and increased antioxidant activity. ${ }^{76}$

Memory impairment, oxidative stress and reduction of acetyl choline signaling are the major symbols of Alzheimer's disease. Apple juice also prevents the reduction of acetylcholine depletion connected with aging and oxidative stress and maintains the neuronal communications. ${ }^{79}$ In 2017 Safari et al. ${ }^{83}$ performed a study to investigate the Immunomodulatory potency of ACV and found ACV more effective, act as an immunomodulator on the systemic and mucosal immune response.

\section{CONCLUSION}

ACV (Apple cider vinegar) is a natural healthpromoting food which includes various potential health benefits. Due to the existence of various polyphenolic compounds, it has high antioxidant, anti-inflammatory action, hepatoprotective and anti-cancer action. The antioxidant mechanism defined essential suggestions for a protective effect of ACV not only cancer but also cardiovascular diseases, asthma and potentially diabetes. Similarly, oxidative stress and mutation in gene coding amyloid precursor protein (APP) and aging are the main origins of Alzheimer's disease. However, research data signifying that antioxidant effects are imperative, including the suppression of neurotoxic mediators in Alzheimer's diseases. So regular consumption of ACV as a part of a healthy diet may prevent the oxidative effect of cells which is the main cause of Alzheimer's disease and it could be an economical and recurrent source of dietary antioxidant. Ongoing work continues to define mechanisms behind this followed by in vivo and in vitro experiment.

\section{ACKNOWLEDGEMENT}

This work was supported by Department of pharmaceutical Sciences and Technology, Birla Institute of Technology, Mesra for providing research support. Authors are also gratefully acknowledged to AICTEQIP (All India Council for Technical Education-Quality improvement programme) for providing financial support.

\section{CONFLICT OF INTEREST}

The authors declare no conflict of interest.

\section{ABBREVIATIONS}

AD: Alzheimer's Disease; ACV: Apple Cider vinegar; NFTs: Neurofibrillary tangles; $\mathbf{A} \beta$ : $\beta$-amyloid; APP: Amyloid precursor protein; BACE 1: Beta-secretase 1; GSK3 $\beta$ : Glycogen synthase kinase 3 $\beta$; CDK5: Cyclindependent kinase 5; PHFs: Paired helical filaments structure; PUFs: Polyunsaturated fatty acids; ERK: Extracellular-signal regulated kinase; CREB: Cyclic AMP response element binding protein; COX-2: Cyclooxygenase-2; LDL: Low density lipoprotein; HDL: High density lipoprotein; VLDL: Very low density lipoprotein.

\section{REFERENCES}

1. Prince M, Bryce R, Albanese E, Wimo A, Ribeiro W, Ferri CP. The global prevalence of dementia: A systematic review and meta-analysis. Alzheimer's Dementia. 2013;9(1):63-75.

2. Brookmeyer R, Kawas $\mathrm{CH}$, Abdallah N, Paganini-Hill A, Kim RC, Corrada MM. Impact of interventions to reduce Alzheimer's disease pathology on the prevalence of dementia in the oldest-old. Alzheimer's Dementia. 2016;12(3):225-32.

3. Polidori MC, Pientka L, Mecocci P. A review of the major vascular risk factors related to Alzheimer's disease. J Alzheimer's Dis. 2012;32(3):521-30.

4. Huang $Y$, Mucke L. Alzheimer mechanisms and therapeutic strategies. Cell. 2012;148(6):1204-22.

5. Ferri CP, Prince M, Brayne C, Brodaty $\mathrm{H}$, Fratiglioni L, Ganguli M, et al. Global prevalence of dementia: A Delphi consensus study. Lancet. 2005;366(9503):2112-7.

6. Evans DA, Funkenstein HH, Albert MS, Scherr PA, Cook NR, Chown MJ, et al. Prevalence of Alzheimer's disease in a community population of older persons. Higher than previously reported. JAMA. 1989;262(18):2551-6.

7. Ferri $\mathrm{CP}$, Prince $\mathrm{M}$, Brayne $\mathrm{C}$, Brodaty $\mathrm{H}$, Fratiglioni $\mathrm{L}$, Ganguli $\mathrm{M}$, et al. Alzheimer's Disease International. Global prevalence of dementia: A Delphi consensus study. Lancet. 2005;366(9503):2112-7.

8. Masliah E, Mallory M, Alford M, DeTeresa R, Iwai A, Saitoh T. Molecular Mechanisms of Synaptic Disconnection in Alzheimer's Disease. Connections Cognition and Alzheimer's Disease. 1997;121-40.

9. Terry RD, Masliah E, Hansen LA. Structural Basis of the Cognitive Alterations in Alzheimer Disease. American Psychological Association. 1994;179-96.

10. DeKosky ST, Scheff SW, Styren SW. Structural correlates of cognition in dementia: Quantification and assessment of synapse change. Neurodegeneration. 1996;5(4):417-21.

11. Iwata N, Tsubuki S, Takaki Y, Shirotani K, Lu B, Gerard NP, et al. Metabolic regulation of brain Abeta by neprilysin. Science. 2001;292(5521):1550-2. 
12. Lee J, Retamal C, Cuitiño L, Caruano-Yzermans A, Shin JE, Kerkhof PV, et al. Adaptor protein sorting nexin 17 regulates amyloid precursor protein trafficking and processing in the early endosomes. J Biol Chem. 2008;283(17):11501-8.

13. Meziane H, Dodart JC, Mathis C, Little S, Clemens J, Paul S, et al. Memoryenhancing effects of secreted forms of the beta amyloid precursor protein in normal and amnestic mice. Proc Natl Acad Sci. 1998;95(21):12683-8.

14. Bendiske J, Bahr BA. Lysosomal activation is a compensatory response against protein accumulation and associated synaptopathogenesis: An approach for slowing Alzheimer disease. J Neuropathol Exp Neurol. 2003;62(5):451-63.

15. Geschwind $\mathrm{DH}$. Tau phosphorylation, tangles and neurodegeneration: The chicken or the egg. Neuron. 2003;40(3):457-60.

16. Mayeux R, Stern Y. Epidemiology of Alzheimer Disease. Cold Spring Harb Perspect Med. 2012;2(8):a006239.

17. Barba R, Martinez-Espinosa S, Rodriguez-Garcia E, Pondal M, Vivancos J, DelSer T. Poststroke dementia: Clinical features and risk factors. Stroke. 2000;31(7):1494-501.

18. Desmond DW, Moroney JT, Sano M, Stern Y. Incidence of dementia after ischemic stroke: Results of a longitudinal study. Stroke. 2002;33(9):2254-60.

19. DeKoning I, Kooten FV, Koudstaal PJ, Dippel DW. Diagnostic value of the Rotterdam-CAMCOG in post-stroke dementia. J Neurol Neurosurg Psychiat. 2005;76(2):263-5.

20. Zhu L, Fratiglioni L, Guo Z, Basun H, Corder EH, Winblad B, et al. Incidence of dementia in relation to stroke and the apolipoprotein $E \& 4$ allele in the very old: Findings from a Population-based Longitudinal Study. Stroke. 2000;31(1):53-60

21. Henon H, Durieu I, Guerouaou D, Lebert F, Pasquier F, Leys D. Poststroke dementia: Incidence and relationship to prestroke cognitive decline. Neurology. 2001;57(7):1216-22.

22. www.acimmune.com.

23. Honig LS, Tang MX, Albert S, Costa R, Luchsinger J, Manly J, et al. Stroke and the risk of Alzheimer disease. Arch Neurol. 2003;60(12):1707-12.

24. Klimkowicz A, Dziedzic T, Slowik A, Szczudlik A. Incidence of pre- and poststroke dementia: Cracow Stroke Registry. Dement Geriatr Cogn Disord. 2002;14(3):137-40.

25. www.healthline.com.

26. Vauzour D, Martinsen A, Lay'e S. Neuroinflammatory processes in cognitive disorders: Is there a role for flavonoids and n-3 polyunsaturated fatty acids in counteracting their detrimental effects. Neurochemistry International. 2015;89:63-74.

27. Zandi PP, Anthony JC, Khachaturian AS, Stone SV, Gustafson D, Tschanz JT, et al. Cache County Study Group. Reduced risk of Alzheimer disease in users of antioxidant vitamin supplements: The Cache County Study. Archives of Neurology. 2004;61(1):82-8.

28. Dysken MW, Sano M, Asthana S, et al. Effect of vitamin E andmemantine on functional decline in Alzheimer disease: The TEAM-AD VA cooperative randomized trial. Journal of the American Medical Association. 2014;311(1):33-44.

29. Raszewski G, Chwedorowicz R, Chwedorowicz A, Rothenberg KG. Homocysteine, antioxidant vitamins and lipids as biomarkers of neurodegeneration in Alzheimer's disease versus non-Alzheimer's dementia. Annals of Agricultural and Environmental Medicine. 2016;23(1):193-6.

30. Chen H, Liu S, Ji L, et al. Associations between Alzheimer's disease and blood homocysteine, vitamin B12 and folate: A case-control study. Current Alzheimer Research. 2015;12(1):88-94.

31. Takasaki J, Ono K, Yoshiike Y, et al. Vitamin A has anti oligomerization effects on amyloid- $\beta$ in vitro. Journal of Alzheimer's Disease. 2011;27(2):271-80.

32. Choi DY, Lee YJ, Hong JT, Lee HJ. Antioxidant properties of natural polyphenols and their therapeutic potentials for Alzheimer's disease. Brain Research Bulletin. 2012;87(2):144-53

33. Hamaguchi T, Ono K, Murase A, Yamada M. Phenolic Compounds Prevent Alzheimer's Pathology through Different Effects on the Amyloid- $\beta$ Aggregation Pathway. The American Journal of Pathology. 2009;175(6):2557-65.

34. Kean RJ, Lamport DJ, Dodd GF, et al. Chronic consumption of flavanone-rich orange juice is associated with cognitive benefits: An 8-wk, randomized, double-blind and placebo controlled trial in healthy older adults. The American Journal of Clinical Nutrition. 2015;101(3):506-14.
35. Shukitt-Hale B, Lau FC, Josep JA. Berry fruit supplementation and the aging brain Journal of Agricultural and Food Chemistry. 2008;56(3):636-41.

36. Rendeiro C, Spencer JPE, Vauzour D, Butler LT, Ellis JA, Williams CM. The impact of flavonoids on spatial memory in rodents: From behavior to underlying hippocampal mechanisms. Genes and Nutrition. 2009;4(4):251-70.

37. DeNicol'o S, Tarani L, Ceccanti M, Maldini M, Natella F, Vania A, et al. Effects of olive polyphenols administration on nerve growth factor and brain derived neurotrophic factor in the mouse brain. Nutrition. 2013;29(4):681-7.

38. Scalbert A, Manach C, Morand C, Re'me'sy C, Jime'nez L. Dietary polyphenols and the prevention of diseases. Crit Rev Food Sci Nutr. 2005;45(4):287-306.

39. Crozier A, Yokota T, Jaganath IB, Marks SC, Saltmarsh M, Clifford MN. Secondary metabolites in fruits, vegetables, beverages and other plant based dietary components. In Plant Secondary Metabolites: Occurrence, Structure and Role in the Human Diet. 2006;208-302.

40. Budak HN, Kumbul DD, Savas CM, Seydim AC, Tas TK, Ciris IM, et al. Effects of apple cider vinegars produced with different techniques on blood lipids in highcholesterol-fed rats. J Agric Food Chem. 2011;59(12):6638-44.

41. Budak HB, Guzel-Seydim ZB. Antioxidant activity and phenolic content of wine vinegars produced by two different techniques. J Sci Food Agric. 2010;90(12):20216.

42. Alonso AM, Castro R, Rodriguez MC, Guillen DA, Barroso CG. Study of the antioxidant power of brandies and vinegars derived from Sherry wines and correlation with their content in polyphenols. Food Res Intl. 2004;37(7):715-21.

43. Plessi M, Bertelli D, Miglietta F. Extraction and identification by GC-MS of phenolic acids in traditional Balsamic vinegar from Modena. J Food Compost Anal. 2006;19(1):49-54.

44. DelCampo G, Berregi I, Santos JI, Dueñas M, Irastorza A. Development of alcoholic and malolactic fermentations in highly acidic and phenolic apple musts. Bioresour Technol. 2008;99(8):2857-63.

45. Abe K, Arai R, Kushibiki T, Sasaki JI, Matsue H. Antitumor-active, Neutral, Mediumsized Glycan from Apple Vinegar. Food Sci Biotechnol. 2001;10:534-8.

46. Barth SW, Fähndrich $\mathrm{C}$, Bub A, Dietrich $\mathrm{H}$, Watzl B, Will F, et al. Cloudy apple juice decreases DNA damage, hyperproliferation and aberrant crypt foci development in the distal colon of $\mathrm{DMH}$-initiated rats. Carcinogenesis. 2005;26(8):1414-21.

47. Schiavano GF, DeSanti M, Brandi G, Fanelli M, Bucchini A, Giamperi L. Inhibition of breast cancer cell proliferation and in vitro tumorigenesis by a new red apple cultivar. PLoS One. 2015;10(8):e0135840.

48. Hung $\mathrm{CH}$, Huang $\mathrm{CC}$, Hsu LS, Kao SH, Wang CJ. Apple polyphenol inhibits colon carcinoma metastasis via disrupting Snail binding to focal adhesion kinase. J Func Foods. 2015;12:80-91.

49. Kao YL, Kuo YM, Lee YR, Yamg SF, Chen WR, Lee HJ. Apple polyphenol induces cell apoptosis, cell cycle arrest at G2/M phase and mitotic catastrophe in human bladder transitional carcinoma cells. J Func Foods. 2015;14:38494.

50. Clarissa G. Cancer Chemopreventive Potential of Apples, Apple Juice and Apple Components. Planta Med. 2008;74(13):1608-24.

51. Shishehbor F, Mansoori A, Sarkaki AR, Jalali MT, Latifi SM. Apple cider vinegar attenuates lipid profile in normal and diabetic rats. Pak J Biol Sci. 2008;11(23):2634-8.

52. Jiang T, Gao X, Wu C, Tian F, Lei Q, Bi J, et al. Apple- derived pectin modulates gut microbiota, improves gut barrier function and attenuates metabolic endotoxemia in rats with diet-induced obesity. Nutrients. 2016;8(3):126.

53. Bouderbala $\mathrm{H}$, Kaddouri $\mathrm{H}$, Kheroua $\mathrm{O}$, Saidi D. Anti- obesogenic effect of apple cider vinegar in rats subjected to a high fat diet. Ann Cardiol Angeiol. 2016;65(3):208-13.

54. Fathy SM, Drees EA. Protective effects of Egyptian cloudy apple juice and apple peel extract on lipid peroxidation, antioxidant enzymes and inflammatory status in diabetic rat pancreas. BMC Complement Altern Med. 2016;16(1):8.

55. Morgan J, Mosawy S. The Potential of Apple Cider Vinegar in the Management of Type 2 Diabetes. International Journal of Diabetes Research. 2016;5(6):129-34

56. Nicklas TA, O'Neil CE, Fulgoni VL. Consumption of various forms of apples is associated with a better nutrient intake and improved nutrient adequacy in diets of children: National Health and Nutrition Examination Survey 20032010. Food Nutr Res. 2015;14:48. 
57. Fathy SM, Drees EA. Protective effects of Egyptian cloudy apple juice and apple peel extract on lipid peroxidation, antioxidant enzymes and inflammatory status in diabetic rat pancreas. BMC Complement Altern Med. 2016;16(1):8.

58. Nazıroğlu M, Güler M, Özgül C, Saydam G, Küçükayaz M, Sözbir E. Apple cider vinegar modulates serum lipid profile, erythrocyte, kidney and liver membrane oxidative stress in ovariectomized mice fed high cholesterol. J Membr Biol. 2014;247(8):667-73.

59. Espley RV, Butts CA, Laing WA, Martell S, Smith H, McGhie TK, et al. Dietary flavonoids from modified apple reduce inflammation markers and modulate gut microbiota in mice. J Nutr. 2014;144(2):146-54.

60. Lee WC, Jao HY, Hsu JD, Lee YR, Wu MJ, Kao YL, et al. Apple polyphenols reduce inflammation response of the kidneys in unilateral ureteral obstruction rats. J Func Foods. 2014;11:1-11.

61. Yang J, Li Y, Wang F, Wu C. Hepatoprotective effects of apple polyphenols on CCl4- induced acute liver damage in mice. J Agric Food Chem. 2010;58(10):6525-31.

62. Budak NH, Kumbul DD, Savas CM, Seydim AC, Kok TT, Ciris MI, et al. Effects of apple cider vinegars produced with different techniques on blood lipids in high-cholesterol-fed rats. J Agric Food Chem. 2011;59(12):6638-44.

63. Denis MC, Furtos A, Dudonne' S, Montoudis A, Garofalo C, Desjardins Y, et al. Apple peel polyphenols and their beneficial actions on oxidative stress and inflammation. PLoS One. 2013;8(1):e53725.

64. Cheng D, Zhu C, Wang C, Xu H, Cao J, Jiang W. Hepatoprotective effects of apple polyphenol extract on aluminum-induced liver oxidative stress in the rat. Can J Physiol Pharmacol. 2014;92(2):109-16.

65. Kuźniak VK, Szaefer H, Ignatowicz E, Adamska T, Markowski J, BaerDubowska W. Influence of cloudy apple juice on n-nitrosodiethylamineinduced liver injury and phases I and II biotransformation enzymes in rat liver. Acta Pol Pharm. 2015;72:267-76.

66. DeGomes MCF, Pidone RFA, Lucke G, Boiago GAP, Fujiyama OCT, Ribeiro DA. Apple juice attenuates genotoxicity and oxidative stress induced by cadmium exposure in multiple organs of rats. J Trace Elem Med Biol. 2015;32:7-12

67. Wu Z, Xia Z, Wu B, Wei F, Lv X, Xie Y, et al. Lipid profiling in serum from apolipoprotein E-knock out mice fed with different diets and its application to the study of the regulatory effect on lipid metabolism. Food Funct. 2018;9(10):510314.

68. Vineetha VP, Girija S, Soumya RS, Raghu KG. Polyphenol- rich apple (Malus domestica L.) peel extract attenuates arsenic trioxide induced cardiotoxicity in H9c2 cells via its antioxidant activity. Food Funct. 2014;5(3):502-11.

69. Hodgson JM, Prince RL, Woodman RJ, Bondonno CP, Ivey KL, Bondonno N, et al. Apple intake is inversely associated with all-cause and disease-specific mortality in elderly women. Br J Nutr. 2016;115(5):860-7.
70. Laranjinha JA, Almeida LM, Madeira VM. Reactivity of dietary phenolic acids with peroxyl radicals: Antioxidant activity upon low density lipoprotein peroxidation. Biochem Pharmacol. 1994;48(3):487-94.

71. Lu Y, Foo LY. Antioxidant and radical scavenging activities of polyphenols from apple pomace. Food Chemistry. 2000;68(1):81-5.

72. Seydim AC, Guzel-Seydim ZB, Doguc DK, Savas MC, Budak HN. Effects of grape wine and apple cider vinegar on oxidative and antioxidative status in high cholesterol-fed rats. Functional Foods in Health and Disease. 2016;6(9):569-77.

73. Yagnik D, Serafin V, Shah AJ. Antimicrobial activity of apple cider vinegar against Escherichia coli, Staphylococcus aureus and Candida albicans: Downregulating cytokine and microbial protein expression. Scientific Reports. 2018;8(1):1732

74. Mota AC, DeCastro RD, DeAraújo OJ, DeOliveira LE. Antifungal Activity of Apple Cider Vinegar on Candida Species Involved in Denture Stomatitis. J Prosthodont. 2015;24(4):296-302.

75. Hyson DA. A Comprehensive Review of Apples and Apple Components and Their Relationship to Human Health. Adv Nutr. 2011;2(5):408-20.

76. Tchantchou F, Chan A, Kifle L, Ortiz D, Shea T. Apple juice concentrate prevents oxidative damage and impaired maze performance in aged mice. $\mathrm{J}$ Alzheimers Dis. 2005;8:283-7.

77. Rogers EJ, Mihalik S, Ortiz D, Shea T. Apple juice prevents oxidative stress and impaired cognitive performance caused by genetic and dietary deficiencies in mice. J Nutr Health Aging. 2004;8(2):92-7.

78. Tchantchou F. Dietary supplementation with apple juice concentrate alleviates the compensatory increase in glutathione synthase transcription and activity that accompanies dietary- and genetically-induced oxidative stress. J Nutr Health Aging. 2004;8(6):492-6.

79. Chan A, Graves V, Shea T. Apple juice concentrate maintains acetylcholine levels following dietary compromise. J Alzheimers Dis. 2006;9(3):287-91.

80. Chan A, Shea T. Supplementation with apple juice attenutates presenilin1overexpression during dietary and genetically-induced oxidative stress. J Alzheimers Dis. 2006;10(4):353-8.

81. Chan A, Shea T. Dietary supplementation with apple juice decreases endogenous amyloid-beta levels in murine brain. $\mathrm{J}$ Alzheimers Dis. 2009;16(1):176-71.

82. Chan A, Shea T. Folate deprivation increases presenilin expression, gammasecretase activity and A-beta levels in murine brain: Potentiation by ApoE deficiency and alleviation by dietary S-adenosyl methionine. J Neurochem. 2007;102(3):753-60.

83. Safari R, Hoseinifar SH, Nejadmoghadam S, Khalili M. Apple cider vinegar boosted immunomodulatory and health promoting effects of Lactobacillus casei in common carp (Cyprinus carpio). Fish Shellfish Immunol. 2017;67:441-8.

Cite this article: Tripathi S, Mazumder PM. Apple Cider Vinegar (ACV) and their Pharmacological Approach towards Alzheimer's Disease (AD): A Review. Indian J of Pharmaceutical Education and Research. 2020;54(2s):s67-s74. 